\title{
GEORG LUKÁCS: PARA UMA CRÍTICA DO TATICISMO STALINISITA
}

\author{
GEORG LUKÁCS: FOR A CRITICISM OF STALINISITE TACTICISM
}

Henrique Leão Coelho*

\begin{abstract}
RESUMO
O texto em tela procura tornar eminentes algumas reflexões oportunadas por Georg Lukács acerca da degradação do marxismo consignada pelo stalinismo. Para isso, faz-se necessário considerarmos o "retorno a Marx" promovido pelo filósofo, depois de longo percurso imantado às filosofias idealistas. No que concerne a essa problemática, o texto traz à tona o emblemático ensaio Meu caminho para Marx, no qual o autor húngaro traça, em linhas sintéticas, seu trajeto de recuperação teórica, superação da verve idealista subjetiva e objetiva que tergiversavam a assimilação do marxismo autêntico. Em seguida, nos deteremos aos pontos centrais daquela crítica de Lukács (ao fenômeno do stalinismo), no texto Cartas sobre o stalinismo, em que poderemos averiguar a renovada e marxista parametração crítica do autor que vivenciou de perto a degradação ideológica aqui tematizada. Trata-se, em outras linhas, de aprofundar nos escaninhos históricos do marxismo e, pela via do autor húngaro, averiguar a atividade crítico-prática mediante a altura ideativa alcançada acerca da designada "inteligência das coisas".
\end{abstract}

PALAVRAS-CHAVE: Marxismo. Lukács. Stalinismo. Marx. Taticismo.

\section{ABSTRACT}

The text in question seeks to make eminent some reflections opportunized by Georg Lukács about the degradation of Marxism consigned by Stalinism. For this, it is necessary to consider the "return to Marx" promoted by the philosopher, after a long journey magnetized to idealistic philosophies. With regard to this problem, the text brings up the emblematic essay Meu caminho para Marx, where the Hungarian author traces in synthetic lines, his path of theoretical recovery, overcoming the subjective and objective idealistic verve that doubted the assimilation of authentic Marxism. Then, we will focus on the central points of that criticism by Lukács (to the phenomenon of Stalinism), in the text Letters on Stalisnism, where we will be able to ascertain the renewed and Marxist critical parameterization of the author who experienced the ideological degradation discussed here. In other lines, it is a matter of deepening the historical bins of Marxism and, through the Hungarian author, evaluating a critical-practical activity using an ideational height reached on the so-called "intelligence of things".

KEYWORDS: Marxism. Lukács. Stalinism. Marx. Tacticism.

\footnotetext{
* Doutorando na linha de Estudos organizacionais, trabalho e sociedade em Administração (UFMG). E-mail: rickcoelholda@hotmail.com.
} 


\title{
INTRODUÇÃO
}

Georg Lukács, tendo como guia sua perspectiva voluntarista e idealista até meados dos anos 20, não deixou de tecer desvelações críticas de agudo proveito para a exegese da ciência burguesa (LUKÁCS, 2012). Nessa tônica, para além do anticapitalismo romântico de $A$ história do drama moderno (1908) e, mesmo, do pessimismo aglutinado em A alma e as formas (1910), A teoria do romance (1915) e História e consciência de classe (1923), livros intermediados por Tática e ética (1919), são textos que nos trazem a crítica da "perda da totalidade" no campo da reflexão conceitual; crítica, que mesmo em sua incipiência quanto ao empenho marxista, reverbera e explicita os flancos frágeis da ideologia burguesa decadente.

Não olvidando tais trabalhos, José Paulo Netto (1983, p. 43) discorre:

\begin{abstract}
De acordo com o Lukács de 1923, há uma fratura ineliminável entre o marxismo e a ciência burguesa: a sociedade só pode ser cientificamente estudada a partir do "ponto de vista da totalidade", capaz de resolver as formas sociais nos seus processos; ora, na sociedade moderna, somente as classes representam o ponto de vista da totalidade, mas só o proletariado, partindo dele, pode conhecer a realidade, já que "a sobrevivência da burguesia pressupõe que ela jamais alcance uma clara compreensão das condições da sua própria existência". O marxismo, consciência teórica do proletariado, é a ciência social; nele, ao mesmo tempo, o proletariado, sujeito e objeto do conhecimento, realiza-se adquirindo a sua autoconsciência. Para o proletariado, conhecer-se significa conhecer a sociedade - e este conhecimento é a única garantia do êxito da ação revolucionária. Apenas ao proletariado, graças à sua posição na sociedade burguesa — que determina a sua "missão histórica" —, a prática revolucionária pode aparecer como projeto consciente. Para tanto, é-lhe preciso romper com a imediaticidade (ou seja, a aparência positiva, reificada, coisificada) da vida social, e isto não se faz automaticamente: o proletário deve avançar da sua consciência individual (psicológica) para o nível da consciência de classe - a consciência possível das transformações que conduzam à libertação da classe e da humanidade. Este salto, regido pela consciência teórica do movimento (o marxismo) e operado na ação, implica o partido, "forma de mediação entre a teoria e a prática".
\end{abstract}

Vejamos que o percurso heurístico de Georg Lukács, mesmo em seus brotamentos intelectivos, traz à tona elementos de rica fundamentação para uma crítica social agudamente desveladora da imanência social; insumos de pertinência e relevância para a consciência de classe mais aguçada quanto à possibilidade de transformação do padrão das relações sociais. Sociabilidade como objeto que só é possível ser estudado "a partir do ponto de vista da totalidade"; crítica eminente sobre a parcelarização e a autorreferenciação dos complexos sociais, movimento de degradação da racionalidade e do próprio objeto de estudo engendrado pela ciência burguesa. No entanto, mesmo nessas conquistas críticas, fica manifesto que o conteúdo marxista lukasciano é ainda atrvessado fortemente pelo vínculo lógico Hegel-Marx, 
ganhando seu ponto alto em 1923, em História e consciência de classe, em que o proletariado encarna o sujeito-objeto idêntico hegeliano.

Vemos em Lukács, também positivamente, a perseverança ideativa na ultrapassagem da "imediaticidade" da vida social, o necessário social da atividade crítico-prática; consciência que se amplifica pela captação da articulação concreta dos complexos sociais, reverberando no campo conceitual como representação mais aproximativa da hierarquia, especificidade e relacionalidade das esferas a partir do ser. $\mathrm{O}$ autor húngaro não deixa de execrar, também, a concepção do conhecimento proletário espontaneísta, ou seja, "esse salto, regido pela consciência teórica do movimento (o marxismo)", dando o marxismo, desde então, como a ciência social adequada sem a qual a práxis revolucionária se despe da “inteligência das coisas", guia ideológico de elevada objetividade.

As obras objetivadas por Lukács após o clássico História e consciência de classe engendram um longo processo de reparação teórica. Da biografia de Lenin (1924), aos textos de análise da dialética de Bukharin (1925) e de Moses Hess (1926), o autor húngaro deflagra público descortino da tergiversação idealista, caminho de superação da imputação metafísica pelo materialismo consequente e imanente à obra do próprio Marx. Sustentando o processo de recuperação em Reboquismo e dialética (1926) e em Meu caminho para Marx (1933), a obra do filósofo traçava caminho de despedida das ilações subjetivistas, travestidas pelo travessão do Idealismo com tons voluntaristas e messiânicos.

Sabe-se, assumidamente pelo próprio autor, que há uma "guinada marxista e ontológica" em seu pensamento quando a partir 30-31, no Instituto Marx-Engels, em Moscou, o autor tem contato com os Manuscritos econômico-filosóficos de Marx, com os Cadernos filosóficos de Lenin e com as cartas entre Marx e Engels debatendo arte e literatura. A primazia da objetividade enforma a renovação de seu pensamento filosófico e científico, dando azo à correção da influência idealista-hegeliana da relação sujeito-objeto. Além disso, circunscreve a esse próprio movimento recuperativo marxiano, a distinção paulatina dos lineamentos filosóficos fundamentais de Marx, como exemplo nuclear, a diferenciação entre alienação e objetivação (COTRIM, 2009), embora o gradiente estético tenha mais relevância que o filosófico na década recuperativa de 30.

Aprofundando na revitalização lukasciana dos termos filosóficos próprios do autor de Trier (K. Marx), pode-se inclusive tecer uma ligação entre sua posição política e sua posição estética maturadas (COTRIM, 2009). A superação da "lente hegeliana" (LUKÁCS, 1983) e a inserção na obra marxiana mesma tem grande marco nas Teses de Blum em que o autor 
repreende qualquer posição idealista sectarista de ultra-esquerda, avançando pela primazia do concreto e de seu conjunto determinativo, para a resolução tático-estratégica da posição socialista (COTRIM, 2009). Se, nesse caso, o bastião tático impôs-se favorável à consecução da ampla frente democrática contra o fascismo, posição que Lukács, posteriormente, nem dirá de tanto valor histórico, terá bastante relevância, por outro lado, seu apreço materialista pela cadeia determinativa do real, configuração diversificada, encadeada e prioritária do concreto. Segundo o próprio húngaro, o grande ganho de Teses é o giro, a passagem de Lukács ao verdadeiro norte materialista, em que o humanismo não plaina desimpedido e absoluto nos ares do idealismo, mas faz contas com realidade efetivamente existente (COTRIM, 2009).

Meu caminho para Marx, de 1933, é, destarte, uma síntese emblemática de um processo longo, por onde a reflexividade lukasciana traça trilha de recuperação, resposta e acerto de contas com a envergadura concreta e processual da própria realidade existente (tendo por base a leitura aprofundada da obra de Marx e Lenin, em seu longo período em Moscou, na década de 30 e 40). É expressão da reparação ideativa, rompante intelectivo que suprime a "boca da filosofia" em prol da "boca da realidade", ou melhor, que faz da reflexão científica de Lukács, pôr teleológico autenticamente expressivo da sociabilidade, porta de entrada à objetividade mesma, na sua condição ontológica de totalidade e processualidade do mundo material social. Vejamos outra asseveração de José Paulo Netto (1983, p. 31):

Do ponto de vista ideológico, a crítica de Lenin impressionou-o profundamente - e, escrevendo um pequeno ensaio logo na sequência da morte do líder bolchevique ( $O$ pensamento de Lenin, 1924), Lukács vê-se no início de um acerto de contas consigo mesmo ao defrontar-se com o antiutopismo leniniano -conduzindo-o a repensar suas tomadas de posição no sentido do que chamou de "realismo revolucionário".

\section{A RECUPERAÇÃO DO MARXISMO AUTÊNTICO COMO RECUPERAÇÃO DA "INTELIGÊNCIA DAS COISAS"}

No texto que agora tomamos, Meu caminho para Marx, vemos de início a constatação definidora de um reenlace teórico que preza pela leitura precisa da obra do autor alemão, matriz cultural de extensivo e intensivo valor teórico. Matriz que precisa ser baliza e parametração para todo pensador que tenha como escopo a elucidação radical do complexo categórico da realidade, pôr teleológico filosófico e científico que aparecerá como "pedra de toque", momento de crivo avançado sobre a representação da realidade. É nesse sentido que Lukács dirá sobre a necessidade da explicitação de cada pensador em relação ao conteúdo 
social da obra marxiana como constatação da realidade, quer dizer, afirmação de "seu lugar nela e seu próprio posicionamento em relação a ela". Não obstante a seriedade de cada autor, para Lukács, tornam-se consequentes a seriedade e a profundidade teóricas que se posicionam frente às lutas histórico-sociais, tendo por caminho, assim, o tracejamento ontológicocientífico de Karl Marx, rompante intelectivo, obra imanentemente colada ao desvelamento profundo da sociabilidade e de suas contradições.

\begin{abstract}
A relação com Marx é a verdadeira pedra de toque para todo intelectual que leva a sério a elucidação da sua própria concepção de mundo, o desenvolvimento social, em particular a situação atual, o seu próprio lugar nela e o seu próprio posicionamento em relação a ela. A seriedade, o escrúpulo e a profundidade com que ele se dedica a esta problemática nos indica em que medida ele quer, consciente ou inconscientemente, esquivar- se de um claro posicionamento com relação às lutas da história atual. Os esboços biográficos que tratam da relação com Marx, da luta espiritual com o marxismo, dão-nos, por vezes, um quadro que, enquanto contribuição à história da luta social dos intelectuais no período imperialista, possui um interesse geral, mesmo quando, como no meu caso, a biografia em si não tenha nenhuma pretensão de interessar ao público. (LUKÁCS, 2010, p. 13).
\end{abstract}

Lukács revela que seu encontro pioneiro com a obra marxiana data do fim de seu período secundário, tendo o Manifesto comunista como ponto de partida. A tônica da escrita de Lukács revela-nos, desde o período secundário ao período universitário, a admiração pela obra do autor alemão, que se amplia frente ao estudo de $O 18$ de Brumário e $O$ capital, ainda que a assimilação da obra de Marx apareça tergiversada pelo seu caráter caudatário ao ecletismo com outras obras filosóficas e científicas.

Foi ao terminar os meus estudos secundários que se deu o meu primeiro encontro com Marx (com o Manifesto Comunista). A impressão foi extraordinária e, quando estudante universitário, li então algumas obras de Marx e Engels (como, por exemplo, O 18 Brumário, A Origem da Família) e, em particular, estudei a fundo o primeiro volume de $\mathrm{O}$ Capital. Esse estudo me convenceu rapidamente da exatidão de alguns pontos centrais do marxismo. Em primeiro lugar, fiquei impressionado com a teoria da mais-valia, com a concepção da história como história da luta de classes e com a articulação da sociedade em classes. Naquele momento, como é óbvio no caso de um intelectual burguês, essa influência se limitou à economia e, sobretudo, à "sociologia". Considerava a filosofia materialista - não distinguia o materialismo dialético do não dialético - completamente superada, enquanto teoria do conhecimento. A tese neokantiana da "imanência da consciência" ajustava-se perfeitamente à minha posição de classe na época; não a submetia a qualquer exame crítico, mas a aceitava passivamente como ponto de partida de toda e qualquer colocação do problema gnosiológico. (LUKÁCS, 2010, p. 13).

A propositura de Lukács traz outro ponto importante para entendermos a fundamentação marxiana por vezes deturpada nas várias formas do marxismo vulgar. A não 
diferenciação entre o materialismo dialético do não dialético, síntese confusa que ampliou a gama teórica formante da irrealização revolucionária: ideologia marxista que apresenta-se também como vulgarização ideológica, fundamentação que não atina para a realidade do ser em si, dando as costas ao materialismo humanista enquanto lineamento ontológico fundamental para o entendimento da determinação recíproca entre a esfera da subjetividade e a esfera da objetividade, centro gravitacional da processualidade social. Assim como posto em Marx, trata-se de apreender o caráter de atividade sensível presente no ser social e não apenas de objeto sensível moldado pela estanque exterioridade.

Adiante, o autor também nos trará outro apontamento de profunda discussão teórica, encetamento já produzido nesse texto, que será agora revestido pela leitura autocrítica do autor húngaro. Lukács (2010) questiona, dessa vez, o Idealismo Subjetivo indo ao centro pontual da discussão, quer dizer, a existência de uma subjetividade autoposta, como se houvesse força autogenética na individualidade. Nesse quesito da imanência da consciência, os vínculos inexoráveis entre subjetividade e objetividade são partidos artificialmente em uma consideração isolada da consciência:

\footnotetext{
$\mathrm{Na}$ verdade, mantinha uma constante suspeita frente ao extremado idealismo subjetivo (tanto o da escola neokantiana de Marburgo quanto o da teoria de Mach), uma vez que não conseguia compreender como era que o problema da realidade podia ser definido, considerando-a simplesmente uma categoria imanente da consciência. (LUKÁCS, 2010, p. 13).
}

Objetemos, portanto, a crítica tecida ao marxismo - de ser, em essência, uma teoria subjetivista - que se firmou sobre base de extensa vulgarização voluntarista ocorrida na história, solfejo negligente à teoria objetivamente embasada. Lukács questiona a qualidade apreensiva da realidade exterior e independente tendo como bússola teórica a categorização absoluta intrassubjetiva, quer dizer, o "problema da realidade" interpretado sobre aporte de "uma categoria imanente da consciência", o que não pode ser de forma alguma imputado ao texto marxiano.

Lukács trará, ainda na forma da autocrítica, o tropeço do ecletismo teóricoepistemológico como solução para uma radicalidade teórica. Sua mudança para a Alemanha, no início década de 1910, período de ganho de intensidade no trajeto do Idealismo Subjetivo influência de origem alemã de autores como Max Weber e Simmel - conduziram-no a um entendimento da sociabilidade atravessado pela filosofia irracionalista, trepidando o conhecimento da totalidade objetiva social de Karl Marx em um sociologismo sem concretude 
material, simples novelo científico que tangencia e alvorece os problemas da esfera cultural como momento preponderante e fundante da ordem social, deixando a esfera econômica marginalizada enquanto objeto da ciência sociológica.

\begin{abstract}
Mas, embora isso não me tenha conduzido a conclusões materialistas, acabou levando-me muito mais a uma aproximação com aquelas escolas filosóficas que queriam resolver este problema de forma irracionalista e relativista e, até muitas vezes, mística (Windelband-Rickert, Simmel, Dilthey). A influência de Simmel, de quem fui discípulo direto, deu-me ainda a possibilidade de "inserir" numa tal concepção de mundo tudo o que havia assimilado de Marx nesse período. A filosofia do dinheiro de Simmel e os escritos sobre o protestantismo de Max Weber foram os meus modelos para uma "sociologia da literatura", na qual os elementos derivados de Marx estavam mais uma vez presentes, mas tão diluídos e empalidecidos que eram quase irreconhecíveis. Seguindo o exemplo de Simmel, eu, de um lado, separava o quanto possível a "sociologia" do fundamento econômico, concebido de modo bastante abstrato, e, de outro lado, via na análise "sociológica" apenas o estágio inicial da verdadeira e real pesquisa científica no campo da estética (História da Evolução do Drama Moderno, 1909; Metodologia da História Literária, 1910, ambas em húngaro). Os meus ensaios publicados entre 1907 e 1911 oscilavam entre este método e um subjetivismo místico. (LUKÁCS, 2010, p. 13).
\end{abstract}

Reverberando a crítica da sociologia, mais tarde, na sua seminal recuperação do marxismo, a Ontologia, Lukács (2012, p. 282) teceria:

\begin{abstract}
Isto pode ser visto claramente através do exemplo de um sábio do nosso tempo, o qual mesmo sendo um cientista escrupuloso, dispunha de vasto e multiforme saber e, não obstante, jamais superou a especialização estreita: refiro-me a Max Weber. Weber era economista, sociólogo, historiador, filósofo e político. Em todos esses campos, tinha à sua disposição profundos conhecimentos, muito superiores à média e, além disso, sentia-se à vontade em todos os campos da arte e da história. Apesar disto, não existe nele qualquer sombra de um verdadeiro universalismo. [...] Por quê? Para responder, é necessário, observar o estado das ciências singulares com a ajuda das quais Weber aspirava atingir um conhecimento universal da história social. Iniciemos pela nova ciência da época da decadência: a Sociologia. Ela surge como ciência autônoma porque os ideólogos burgueses pretendem estudar as leis e a história do desenvolvimento social 'separando-as da economia'. A tendência objetivamente apologética desta orientação não deixa lugar a dúvidas.
\end{abstract}

A crise do entendimento idealista subjetivo aparece para Lukács com o irrompimento da "guerra mundial". Os detalhes dessa travessia não são tão bem descritos pelo autor, mesmo assim, ele demarca sua passagem do Idealismo Subjetivo ao Idealismo Objetivo mediante $A$ teoria do romance, quando "Hegel adquire uma importância cada vez maior". A influência de Ernst Bloch aparece também como referência que leva Lukács ao estudo da filosofia de talhe clássico, quer dizer, filosofiar “como Aristóteles ou Hegel”. Há um conjunto de fatos que vão aproximando-o delicadamente do cerne autêntico da obra marxiana: "o caráter imperialista da guerra mundial", "o aprofundamento dos [meus] estudos de Hegel” e a aproximação em 
relação à obra de Fueurbach.

Vejamos como importa a travessia sobredita: a expurgação do espírito do “epistemologismo" (LUKÁCS, 2012) subjetivista pela tônica hegeliana que, ainda idealista, traz já a importância da elucidação filosófico-científica em direção ao "reboquismo" quanto à importância a ser dada ao próprio ser e à sua racionalidade específica. Vemos nesse sentido a importância de Hegel como polo aglutinador de uma filosofia superior a outros nomes da modernidade já citados. Lukács descreverá que no comboio dessas transformações da segunda metade da década de 10 , os estudos dos livros da filosofia marxiana tornarão o ponto central de sua apreensão, ainda que a "lente de Simmel" tenha sido trocada pela "lente de Hegel".

Chegamos dessa maneira a um ponto de relevância crucial para nossa crítica da fundamentação ideológica: a negação de uma concepção idealista de mundo, de uma prontidão metafísica a ser colocada e aplicada na diversidade das sociedades. É o marxismo vulgar que torna a filosofia marxiana como modelo acabado a ser vestido nas sociedades, ocultando o desenvolvimento particular de cada caso. O delineamento ontológico materialista e histórico-crítico de Marx guia o entendimento científico, aprofundamento apropriado sobre os elementos universais, particulares e singulares do objeto, sem cristalizar em bloco monolítico uma teoria geral da sociedade.

\footnotetext{
Desta vez, porém, não se tratava mais de um Marx visto da lente de Simmel, mas através da perspectiva hegeliana. Marx deixava de ser o "eminente especialista", o "economista e sociólogo"; já começava a delinear-se para mim o grande pensador, o grande dialeta. No entanto, naquela época, ainda não compreendia o significado do materialismo para a concretização, unificação e colocação coerente das questões dialéticas. O máximo que cheguei a postular foi uma prioridade - hegeliana - do conteúdo sobre a forma e procurei, sobre base essencialmente hegeliana, sintetizar Hegel e Marx numa "filosofia da história". (LUKÁCS, 2010, p. 13).
}

Szabó, Lenin e Rosa Luxemburgo foram outras leituras do segundo período da década de 10. Leituras que não radicaram de vez o posicionamento idealista objetivo do jovem húngaro, nem mesmo sob o bojo da intensa atuação partidária do autor, reclamando mais uma vez a negação vital da autoridade cognitiva baseada na prática (voluntarismo):

As revoluções de [19]17 e [19]18 surpreenderam-me no bojo dessa efervescência ideológica. Em dezembro de 1918, depois de breve hesitação, ingressei no Partido Comunista Húngaro e, desde então, permaneci nas fileiras do movimento operário revolucionário. O trabalho prático logo me obrigou a dedicar-me aos escritos econômicos de Marx, a um estudo mais profundo da história, da história econômica, da história do movimento operário etc., empenhando-me, assim, numa contínua

Sapere aude - Belo Horizonte, v. 11 - n. 21, p. 100-120, Jan./Jun. 2020 - ISSN: 2177-6342 
revisão dos fundamentos filosóficos. Todavia, essa luta para dominar a dialética marxista prolongou-se por muito tempo. (LUKÁCS, 2010, p. 13).

A afirmação da dialética materialista permanecia suspensa como apreensão rigorosa do ser social, tisnando a obra de Karl Marx pelas vias, principalmente, do Idealismo Objetivo. O processo de desenvolvimento de Lukács nos importa: encena dificuldade não ultrapassada, uma vez que o marxismo enquanto possível ideologia proponente ao reconhecimento e resposta quanto às questões sociais pertinentes ao presente permanece em larga escala infiltrado pelos mesmos equívocos perpassados pelo autor. Forças deletérias à urgente necessidade social da elevada abstração quanto ao movimento corrente dos conflitos sociais, necessária base ideológica para a ontoprática revolucionária: reflexo crítico adequado que se efetive na orientação da superação da práxis social fetichizada, guiada pelos complexos reprodutores da sociabilidade burguesa.

Mesmo em História e consciência de classe, como ficou dito, o Idealismo Objetivo se preserva como viés não superado. Para além do próprio Idealismo Objetivo, a persistência de aspectos que o autor chamaria de "místicos", como certo grau de messianismo e voluntarismo, que busca na volição a própria ascendência revolucionaria.

\begin{abstract}
O meu livro História e Consciência de Classe (1923) mostra muito claramente essa transição. Apesar da tentativa, já consciente, de superar e "eliminar" Hegel através de Marx, problemas decisivos da dialética foram resolvidos nesta obra de maneira idealista (dialética da natureza, teoria do reflexo etc.). A teoria de Rosa de Luxemburgo sobre a acumulação do capital, à qual ainda me atinha, misturava-se de modo não orgânico com um ativismo subjetivista de ultraesquerda. (LUKÁCS, 2010, p. 14).
\end{abstract}

O entendimento decisivo da dialética marxista concretizou-se no que o autor chamou de "terceiro período" de sua inflexão ao pensamento marxiano, estágio do início da década de 30 em Moscou, onde pode se dedicar com profundidade à obra de Lênin e Marx. O autor já superava seus 45 anos de idade, quando então achava-se diante do fulcro dos próprios equívocos quanto à filosofia-ciência marxiana, detida nos escaninhos persistentes da dialética idealista, nos lampejos simplistas do subjetivismo. É nesse sentido que nos parece uma crítica que, por infelicidade de nosso estado teórico e ideológico disseminado, permanece radical e necessária, tendo por emblema a síntese lukacsciana: “da dialética viva para a rigidez mecânica”, vulgata marxista a renovar-se com invejável vigor. 
Somente agora, depois de quase uma década de trabalho prático e depois de mais de um decênio de esforço intelectual para compreender Marx, é que o caráter total e unitário da dialética materialista se tornou claro em termo concreto para mim. Mas justamente essa clareza trouxe também consigo o reconhecimento de que o verdadeiro estudo do marxismo só está começando agora e não pode mais parar. Porque, como disse Lênin, com toda razão, "o fenômeno é mais rico do que a lei... e por isso a lei, qualquer que seja, é estreita, incompleta, aproximativa". Isto quer dizer: quem tiver a ilusão de ter compreendido, de uma vez por todas, os fenômenos da natureza e da sociedade, baseado num conhecimento, por mais vasto e profundo que seja, do materialismo dialético, terá necessariamente se deslocado da dialética viva para a rigidez mecânica, do materialismo abrangente para a unilateralidade do idealismo. (LUKÁCS, 2010, p. 14).

Dessa forma, não devemos deixar de reiterar: teoria revolucionária para prática revolucionária. O pensamento marxiano entendido como filosofia-ciência social que só poderá indicar e ser guia da práxis social revolucionária - quer dizer, colocar-se funcionalmente como insumo pertinente da ideologia da classe trabalhadora - na medida em que sonegue as tergiversações da "rigidez mecânica", da "unilateralidade do idealismo", seja do racionalismo formal, ou mesmo, no alvoroço da flexibilidade subjetivista do irracionalismo, para edificar-se como plena ontologia materialista e histórico-crítica, "materialismo abrangente" ou "dialética viva":

Por outro lado, a doutrina de Marx, em sua inatacável unidade e totalidade, constitui a arma para a condução da prática, para o domínio dos fenômenos e de suas leis. Se dessa totalidade for destacado (ou apenas subestimado) um só elemento constitutivo, teremos de novo a rigidez e a unilateralidade. Basta que se perca a relação dos momentos uns com os outros, e lá se vai o chão da dialética marxista sobre o qual apoiamos os pés. (LUKÁCS, 2010, p. 14).

Em ponto final, Georg Lukács termina o curto e intenso ensaio revelando a conjunção entre rigor filosófico-científico e ponto de vista de classe já levado em conta em nosso texto quando o autor magiar criticara seu antigo ponto de vista pequeno-burguês. Observemos mais uma vez atentamente a asseveração do húngaro que retoma o pensamento marxiano em seus textos e termos prórpios como "pedra de toque" para a seriedade e profundidade do pensamento social:

Passaram-se mais de 30 anos desde o dia em que, jovem ainda, li pela primeira vez o Manifesto Comunista. O progressivo aprofundamento - ainda que contraditório e não linear - das obras de Marx tornou-se a história do meu desenvolvimento intelectual e, portanto, tornou-se também a história de toda a minha vida, na medida em que ela possa ter algum significado para a sociedade. Parece-me que, no período posterior a Marx, a tomada de posição em relação ao seu pensamento deve constituir o problema central de todo pensador que leve a sério a si próprio, e que o modo e o grau com que ele se apropria do método e dos resultados de Marx determinam o seu 
lugar no desenvolvimento da humanidade. Esse desenvolvimento está determinado pela situação de classe, se bem que essa determinação não é rígida, mas dialética. A nossa posição na luta de classes determina amplamente o modo e o grau que assumimos o marxismo, mas, por outro lado, todo novo progresso nessa adoção nos faz aderir cada vez mais à vida e à práxis do proletariado e redunda beneficamente no aprofundamento da nossa relação com a doutrina marxista. (LUKÁCS, 2010, p. 15).

\title{
PARA UMA CRÍTICA DO TATICISMO STALINISTA: A DEGRADAÇÃO DA "INTELIGÊNCIA DAS COISAS"
}

Saltemos, agora, para outro texto crítico de elevada importância no conjunto da obra de Georg Lukács. Observada, a trajetória anterior, podemos agora nos entreter neste texto que objetiva de maneira mais explícita as posições teóricas lukacsianas quanto à atividade críticoprática autenticamente marxista e comunista. As antigas referências protocolares ao stalinismo (pré-56, relatório de Kuchev), sob o manto da repressão in loco, estão agora dissolvidas e destituídas. Em Cartas sobre o stalinismo (1962) temos, nas palavra de Jose Paulo Netto (1983, p. 74), que:

\begin{abstract}
O seu interesse dirige-se para o entendimento da problemática cultural da era stalinista. Lukács assinala que, sob Stalin, ao contrário da orientação leniniana, as necessidades táticas imediatas subordinaram a elaboração teórica e paralisaram o pensamento marxista, submetendo-o a exigências rasteiramente pragmáticas e oportunistas. Lukács considera o stalinismo como, sobretudo, um método: em política, um oportunismo taticista; na cultura, o administrativismo burocrático que engendra o dogmatismo. A perspectiva da Carta sobre o Stalinismo é dupla: a crítica aos métodos de direção política da autocracia stalinista e a simpatia para com as providências reformadoras de Kruchev, sempre elogiado por Lukács na questão da coexistência pacífica. E ela está presente em dois outros textos marcadamente políticos de Lukács, divulgados em seguida: Contribuição ao Debate entre a China e a União Soviética (1963), no qual o maoísmo é abordado como uma derivação sectária neostalinista e Problemas da Coexistência Cultural (1964), em que o filósofo procura situar a relação do marxismo com as ideias desenvolvidas no mundo capitalista. É neste escrito, aliás, que Lukács formula a proposta em que mais insistiu nos seus últimos anos: "Tanto para a teoria quanto para a prática dos comunistas, o que está na ordem do dia é a exigência de uma assimilação crítica, por parte do marxismo, daquilo que aconteceu de novo após a morte de Lênin, isto é, das transformações estruturais e das tendências de desenvolvimento da vida social que se definiram nas últimas décadas. Há novos fenômenos de massa que não podem ser resolvidos com o apelo a Marx e a Lênin".
\end{abstract}

Neste ensejo, "esta será uma das teses mais repetidas por Lukács nos seus anos derradeiros: os clássicos - Marx, Engels e Lênin - são necessários, mas insuficientes”. Em suma, porque "a compreensão do mundo da segunda metade do século XX exige novas investigações, pesquisas sobre os fenômenos inéditos colocados pelo desenvolvimento contemporâneo do capitalismo" e, ademais, como nos interessa em particular "pelas 
experiências diferenciadas da transição socialista. Em face deste mundo, já não basta invocar as lições dos clássicos". É nesse diapasão que a recuperação do texto lukacsiano é, já na segunda metade do século XX, um arejamento e avanço explicativo que funda raízes para a consecução consequente da crítica vindoura. Assim, "é preciso avançar com análises particulares, estudos concretos. Esta preocupação de Lukács com a precariedade dos esquemas de explicação da realidade atual expressou-se com força na sua observação" conforme a qual "era imprescindível escrever um novo O Capital, para dar conta dos processos e fatos novos ocorrentes no capitalismo tardio". Em suma, "reiteradas vezes ele se referiu a este necessário e possível desenvolvimento do legado dos clássicos como o 'renascimento do marxismo"' (NETTO, 1983, p. 74).

Imprimir uma exegese sobre o stalinismo, mesmo em suor exaustivo, parece-nos impossível de esgotar todas as nuances do fenômeno, que transcende a própria figura de Stalin e o próprio movimento soviético. Esse entendimento ganha reiteração no início da expressão de Lukács, ao examinar o malefício do "culto da personalidade", entretanto integrando tal prejuízo a um senso das proporções sistemático que posicionasse o fenômeno diante de uma degradação ideológica que o transcende e transcende o próprio caso particular russo. Negligenciado, o criterioso senso da medida quanto à fabulação da figura de Stálin, teremos na crítica mordaz da personalidade uma reverberação inquietante e audaz, mas psicologizante, descompreensiva dos fatos em seu sumo.

Começo pela expressão "culto da personalidade". É claro que entendo ser absurdo reduzir o conteúdo e a problemática de um período tão importante da história do mundo ao caráter particular de um indivíduo. Quando eu era estudante, ensinava-se nas universidades alemãs: "Männer machen die Geschichte" (As personalidades marcantes fazem a história). Mas já o meu sociologismo simmeliano ou maxweberiano de então bastava para fazer-me sorrir ante tais declarações retóricas. Que não direi agora, depois de decênios de educação marxista? (LUKÁCS, 1977, p. $1)$.

Oportunizando a explicação do "culto da personalidade", o autor húngaro demonstra com claridade que a personalidade de Stalin fora menos fundamental do que o aparelhamento de um "símbolo staliniano de liderança", que tinha na monolítica instrumentação burocrática, a forma ideológica decadente de transmitir ao corpo político geral, a ascendência teóricoprática do "líder", por isso:

Identificava em Stálin o vértice de uma pirâmide que, alargando-se sempre na direção da base, compunha-se de "pequenos Stálins", os quais, vistos de cima, eram 
os objetos e, vistos de baixo, eram os produtores e mantenedores do "culto da personalidade". Sem o funcionamento regular deste mecanismo, o "culto da personalidade" não teria passado de um sonho subjetivo, de um acidente patológico, e jamais teria podido atingir aquela eficácia social que exerceu durante algumas décadas. (LUKÁCS, 1977, p. 1).

A tarefa de deslindar a genética do culto à personalidade staliniana mostra-se como uma tarefa, portanto, não agregada a um escopo psicologista, ou mesmo uma constatação historiográfica que enalteça o magnetismo pessoal de Stalin, quanto antes de entender a gênese do problema diante da particularidade russa: uma analítica das condições subjetivas diante da primazia da objetividade possibilitadora do êxito da entificação de uma sociedade revolucionada. Ou seja, o "culto da personalidade" não se explica por si só como simples tendência cultural hermética. Assim, expõe Lukács:

Para os homens que pensam e que são verdadeiramente dedicados à causa do progresso, colocava-se necessariamente a questão da gênese social do fenômeno; e foi Togliatti quem formulou o problema pela primeira vez de maneira justa, dizendo que era preciso estudar as condições socais em que surgira e se consolidara o "culto da personalidade", naturalmente com base na dinâmica interna da Revolução Russa. (LUKÁCS, 1977, p. 1).

O autor húngaro nos posiciona diante da causalidade vasta do fenômeno. Operar com a categoria do "culto da personalidade" de maneira segmentada e levianamente espontânea é tornar o postulado marxista e sua heurística dialética como escrutínio do acusativismo, da inoculação barata da má-consciência, desvio quanto à necessidade de descobrir as determinações recíprocas, as redes de possibilidades e influências erigidas entre as esferas da objetividade e da subjetividade. É preciso ir ao campo das possibilidades materiais que fomentam esse fenômeno. Tornemos ao exame detido do mestre húngaro:

De qualquer modo, há de ficar claro para toda pessoa inteligente que o ponto de partida só pode ser a situação interna e internacional em que se processou a revolução proletária russa de 1917 . De um ponto de vista objetivo, é necessário lembrar as devastações da guerra, o atraso industrial, o relativo atraso cultural da Rússia (analfabetismo, etc.), a série de guerras civis, as intervenções estrangeiras, etc. Como elemento subjetivo (que é frequentemente desprezado), é necessário recordar a posição de Lênin em face da possibilidade de pôr em prática as suas justas teorias. Hoje - já que naqueles anos as suas decisões acabaram sempre por se impor - tende-se a esquecer as resistências que Lênin teve de superar internamente, no partido. (LUKÁCS, 1977, p. 2).

Vejamos que Lukács, ainda que de maneira breve e sintética, procura destinar as linhas de seu texto à investigação da articulação das condições objetivas e das condições 
subjetivas. Doravante, elementos da debilidade no campo da cultura e da insuficiência estrutural da economia russa tornam-se fatores relevantes para o autor. Formas de atraso, enquisto obliterador à pujança revolucionária, obstáculos que possibilitavam o desmanche das conquistas revolucionárias e a ascendência das formas de regressividade no campo da teoria e da prática política, sem no entanto desprezar o "elemento subjetivo".

\begin{abstract}
Após a morte de Lênin, terminara o período das guerras civis e das intervenções estrangeiras, mas, especialmente no que concerne a estas últimas, não havia a menor garantia de que não recomeçariam de uma hora para outra. $\mathrm{O}$ atraso econômico e cultural aparecia como obstáculo difícil de ser superado numa reconstrução do país que devia ser, ao mesmo tempo, edificação do socialismo e proteção contra qualquer tentativa de restauração capitalista. Com a morte de Lênin, naturalmente, as dificuldades internas no partido aumentaram bastante. Já que a onda revolucionária que se tinha desencadeado em 1917 passara sem instaurar uma ditadura do proletariado estável também em outros países, era preciso enfrentar resolutamente o problema da construção do socialismo em um só país (que era um país atrasado). Neste período Stálin se revelou um estadista notável e que via longe. Sua enérgica defesa da nova teoria leninista quanto à possibilidade do socialismo em um só país, contra os ataques sobretudo de Trotski, representou, como não se pode deixar de reconhecer hoje, a salvação da revolução soviética. É impossível fazer justiça histórica a Stálin sem considerar deste ponto de vista a luta de tendências havida no partido comunista. (LUKÁCS, 1977, p. 2).
\end{abstract}

Nesse momento, Lukács, a nosso ver, de maneira equivocada, traz também alguns posicionamentos que demonstram os equívocos teóricos de Trotsky. Em primeiro lugar, "no caso de Trotsky, que foi o principal defensor teórico da tese de que a construção do socialismo em um só país era impossível”, Lukács assevera: “a história refutou, faz tempo, a sua teoria", persistindo explicitamente, nesse momento, na tese da possibilidade do "socialismo em um só país", o que se apresenta, em nosso entender, com o decurso do tempo, um erro de apreensão. Ocasionando, por sua vez, uma razão parcial de Stalin contra a teoria trotskysta, quer dizer, um acerto estratégico contra a possibilidade de recapitulação ao momento pré-revolucionário, o equívoco considerativo da impossibilidade de socialismo em um só país e a íntegra posição pela continuidade revolucionária. Georg Lukács chamará ainda de "lenda", o posicionamento que vê em Trotsky uma figura menos autoritária que Stalin, unificando os posicionamentos burocratistas de Stalin e Trostky contra o verdadeiro interesse teórico da classe trabalhadora representados na prática leniniana: conjunto crítico-prático possibilitador da designada “democracia proletária”. Observemos a seguinte síntese:

Trotski sustentava então, contra Lênin, a tese de que era preciso estatizar os sindicatos para incrementar de maneira mais eficaz a produção, o que significava que objetivamente os sindicatos deviam deixar de ser organizações de massa com 
uma vida própria. Lênin, que partia do exame da situação concreta e defendia o sentido da democracia proletária nas relações dos sindicatos com o partido, e o poder central, empreendia a defesa dos interesses materiais e espirituais dos trabalhadores onde quer que essa defesa se fizesse necessária, e mesmo em face de um Estado burocratizado. Não quero e não posso aqui abordar toda a questão, mas é certo que Stálin, nos anos que se seguiram, prosseguiu de fato (ainda que não na argumentação) na linha de Trotski e não na linha de Lênin. Assim, se mais tarde Trotski acusou Stálin de ter-se apropriado do seu programa, pode-se dizer que neste ponto, em muitos aspectos, ele tinha razão. Aquilo que hoje consideramos despótico e antidemocrático na época staliniana tem ligações estratégicas bastante estreitas com as ideias de Trotski. Uma sociedade socialista dirigida por Trotski seria pelo menos tão pouco democrática quanto a staliniana e ainda se teria orientado estrategicamente à base do dilema política catastrófica ou capitulação, afastando-se da tese substancialmente justa defendida por Stálin acerca do socialismo em um só país. (LUKÁCS, 1977, p. 2).

O stalinismo, entretanto - fica manifesta a apreensão de Lukács -, referenciou-se como deletério taticismo que desdobrou-se em dogmatismo no campo da cultura e burocratismo estatista no campo da política. A “obtenção de um ritmo acelerado de produção" como posto problemático da situação objetiva (dado o fracasso das outras revoluções correlatas) conduziu criticamente ao que Lukács designou de pirâmide do culto da personalidade. Ligação que não apresenta uma causalidade simples e direta, mas determinada inter-relação pois as soluções aos problemas materiais de desenvolvimento das forças produtivas apareciam como impossíveis na própria "democracia proletária", implorando a configuração de outros mecanismos de continuidade daquela sociabilidade revolucionada. Os dispositivos stalinianos de destruição do dissenso intrapartidário, o remonte do núcleo central do partido, a burocratização absoluta para resolução dos conflitos político-sociais, a degradação dogmatista da ambientação cultural pelas diretrizes político-burocráticas e os expurgos. Assim, vemos preservado até um nuance de espanto na fala de Lukács (1977, p. 4):

Do ponto de vista teórico, mesmo, seria necessário mostrar de que maneira Stálin,
que, na década de vinte, defendia com habilidade e inteligência e herança de Lênin,
passou à oposição a este no que concerne a tantos problemas importantes.
(Circunstância que não é alterada pela adesão verbal sempre mantida às doutrinas de
Lênin). Tendo logrado ser tido como legítimo herdeiro e intérprete sempre
autorizado de Lênin, a ponto de ser reconhecido como o quarto clássico do
marxismo, Stálin pôde chegar a consolidar cada vez mais o fatal preconceito da
identidade entre a teoria especificamente staliniana e os princípios fundamentais do
marxismo.

Vejamos, de maneira mais atenta, a crítica lukacsiana. É patente até aqui a relação ontológica entre o momento reflexivo e o momento da práxis efetivadora. O processo de reintegração dos produtos da práxis ao pulso da intelecção e a afirmação da estatura da 
própria práxis diante do horizonte ideativo que a precede. A miséria staliniana, na esfera subjetiva, vem a ser revelada pelo autor húngaro, pela pobreza apreensiva das mediações: Lukács assevera, em poucas palavras, que os conteúdos tático e estratégico de Stalin pesavam não a concreticidade complexa dos momentos históricos determinados, juízo que pleiteia o melhor reconhecimento das "relações de força" que contingenciam e estruturam a realidade existente. Isto daria à teoria a correta temperatura intelectiva, o posicionamento lúcido quanto ao "modo e medida" da atuação política, em termos mais ampliados, da práxis política como mediação tática da luta social. O empobrecimento categórico do discurso stalianiano refletese, indelevelmente, no empobrecimento da própria intervenção no decurso da história.

\begin{abstract}
Começo por uma questão de método, aparentemente muito abstrata: a tendência staliniana é sempre a de abolir, quanto possível, todas as mediações, e a de instituir uma conexão imediata entre os fatos mais crus e as posições teóricas mais gerais. Precisamente aqui, aparece claramente o contraste entre Lênin e Stálin. Lênin distinguia com clareza entre a teoria, a estratégia e a tática, estudando-as sempre com o maior cuidado e levando em conta todas as mediações existentes entre elas e que frequentemente as relacionam de modo muito contraditório. A autoridade pessoal de Lênin resultara das grandes ações e importantes realizações teóricas a ele devidas, tornando-se algo que chamaríamos de "natural"; Stálin, que não dispunha da mesma autoridade que Lênin, achou um modo de dar uma justificação imediatamente evidente de todas as suas medidas, apresentando-se como a consequência direta e necessária da doutrina marxista-leninista. Para conseguir isso, precisou suprimir todas as mediações e estabelecer ligações imediatas entre a teoria e a prática. Por esta razão, tantas categorias de Lênin desaparecem do horizonte de Stálin; o próprio recuo aparece neste como um avanço. (LUKÁCS, 1977, p. 4).
\end{abstract}

A falta de escrúpulo ontológico aparece como uma forma de arbitrariedade, método que despreza a racionalidade, legalidade imanente à coisidade, ao objeto tratado, e que tem no mentalismo hipostasiado a autoridade teórica para o afunilamento prático. A tônica stalinista, segundo Lukács, chegou a ponto de alterar a própria teoria marxista de maneira inescrupulosa e intencional, como forma de torná-la serva do taticismo burocratista: peia voraz dos critérios da obra marxiana, do primado do objeto, estatura ontológica que se delineia pelo movimento da concreticidade aproximado no espalhamento conceitual.

Dois casos passam a representar a desmedida teórica staliniana como dedução sic et simpliciter: a consolidação da interpretação das condições objetivas chinesas como um modo de produção "feudalista asiático" e, de modo mais trágico, a vinculação soviética ao nazismo em 1939, que se de um lado punha-se como acerto político contingente, recuo tático frente à possibilidade de um enfretamento internacional iminente, tem a virada da vinculação em concordância histórico-estratégica. Nesse sentido, a degradação da análise da realidade tornou 
a teoria um instrumento maleável, flexível a ponto de exercer-se segundo uma autoridade descolada da objetividade. Destarte, "Stálin vinha [ao] encontro assim aos anseios teóricos de muitos pensadores burgueses, para os quais o marxismo seria apenas uma "ideologia" política, como qualquer outra". Nesse caso, ideologia como performance discursiva descomprometida com orientação objetiva e progressista do dever-ser humano e coletivo

É fulcro do stalinismo o desvirtuamento dos princípios gerais em prol da prática cotidiana nitidamente taticista. Referência que vai contra o "renascimento do marxismo", necessária retomada e continuidade da teoria autêntica de Marx, colado ao movimento contínuo da realidade em seus momentos mais complexos e particulares. Nesse sentido, como não olvidamos, temos no Idealismo Subjetivo de Stalin, também uma forma de irracionalismo, de expressividade que se guia pela petulância cognitiva apartada das redes complexas da determinidade do real. Nesse sentido, Lukács (1977, p. 6) demonstrará, crucialmente, a síntese confusa stalinista entre a exegese necessária da esfera objetiva e o objetivismo enquanto naturalismo aplicado pela apologia direta do capital.

\begin{abstract}
Já foi observado o subjetivismo que se manifesta na posição de Stálin. O subjetivismo, efetivamente, constitui um momento fundamental naquele sistema, porém assume a sua forma pura na concepção stalinista do partidarismo. Trata-se de um importante elemento da concepção teórica de Lênin; já em seus trabalhos de juventude, este formulou-lhe os momentos subjetivo e objetivo. O momento subjetivo é claro e simples: uma tomada de posição resoluta na luta de classes. Quando Lênin critica o "objetivismo" dos estudiosos burgueses, contudo, não nega o momento objetivo: refere-se a certo tipo de determinismo que pode degenerar facilmente numa apologia dos fatos entendidos como necessários. Já que o partidarismo materialista pesquisa os acontecimentos de modo mais profundo e concreto, a partir das suas forças motrizes reais, ele é mais rigorosamente objetivo do que o "objetivismo" e valoriza mais profunda e concretamente a objetividade. Com Stálin, todavia, o segundo momento cai por terra; e toda preocupação com a objetividade é rotulada como "objetivismo" e declarada desprezível.
\end{abstract}

Como asseverado, "o partidarismo materialista pesquisa os acontecimentos de modo mais profundo e concreto, a partir das suas forças motrizes reais, ele é mais rigorosamente objetivo que o objetivismo". Nesse sentido, a obra e herança staliniana envergam o monumento da deturpação no âmbito teórico a tal ponto, que quedam as teorias de Lênin e de Marx em mecanismo utilitarista, "bíblia do partidarismo", como meros recursos flexíveis para ação. Lukács se lembra da própria edificação de Hegel pelo nazismo como filósofo representante da reação, tendo na deturpação da teoria de caráter progressista do autor alemão um fato explícito dos intentos stalinistas. A deturpação de Hegel, que gerou a própria condenação do autor pelo partido comunista, teve como resposta de Lukács o livro O jovem 
Hegel (escrito por volta de 1938), que buscava refletir a obra de Hegel com a precisão histórica necessária. É nesse sentido que Georg Lukács aponta que o "reconhecimento dos fatos aparecia sempre como objetivismo", ou seja, inflexão taticista como força multifacetada do propagandismo soviético, degenerescência radical das abstrações de alto valor.

O stalinismo como suspensão rigorosa do reconhecimento dialético, como escaninho dogmatista, burocratista e taticista, que erige a agitação e a propaganda como momento prioritário:

\begin{abstract}
O ponto culminante desta tendência está representado pela História do Partido, difundida em muitos milhões de exemplares. Aqui, o partidarismo do funcionário supremo aparece como um demiurgo que cria ou suprime os fatos de acordo com as exigências, conferindo ser e valor aos homens e aos acontecimentos - ou anulandoos. É uma história de lutas entre correntes, mas as oposições são anônimas, não são representadas ou defendidas por homens. É uma história onde (à parte Lênin, bem entendido) só Stálin possui uma existência concreta. Na primeira edição, ainda havia uma exceção: Ezov, o organizador dos primeiros grandes processos judiciais, comparado a "o nosso Marat"; depois que caiu em desgraça, também o seu nome foi suprimido. Em tudo isso, se revela um outro aspecto metodológico. Para os clássicos do marxismo era óbvio que a ciência fornecia o material e os pontos de vista com base nos quais eram tomadas as decisões políticas. Propaganda e agitação recebiam o seu material da ciência, da práxis cientificamente elaborada; Stálin inverteu esta relação. Para ele, em nome do partidarismo, a agitação torna-se o momento primário. (LUKÁCS, 1977, p. 7).
\end{abstract}

A degradação do pôr teleológico estético também é relembrado por Lukács (1977, p. 7), que em sua revista literária, na década de 30 e 40, denunciou, por vezes, a leniência dos stalinistas quanto à arte realista crítica em prol do realismo soviético, ilustração padronizada das decisões partidárias, sintoma inerente ao dogmatismo perpetrado.

Toda a ciência e toda a literatura deviam servir exclusivamente às exigências propagandísticas formuladas pela alta direção, quer dizer, por Stálin. A compreensão e elaboração autônoma da realidade através da literatura era cada vez mais erradicada. A literatura "partidária" já não deve refletir criadoramente a realidade objetiva, mas ilustrar de forma literária as decisões do partido.

É derivado dessas condições que ao pensamento burguês torna-se fundamental sinonimizar a estatura do pensamento marxiano ao simplório processo aderido pelo stalinismo, marginalizando a fecunda obra de Marx enquanto põe em tela, e sob holofotes, o "socialismo real". Aos próprios marxistas, as tendências stalinistas também não se apresentam como contradições plenamente evitáveis: “os que se pretendem socialistas, porque é muito mais cômodo governar com os métodos stalinistas do que com os métodos de Marx, Engels e Lênin” (LUKÁCS, 1977, p. 7). 
É por isso também, como Netto instaura no início de nossos escritos, a pertinência da "cultura socialista" em retomar uma cultura em direção ao universalismo, ao reencontro com a crítica da generidade posta, objetivando pelos pôres teleológicos (LUKÁCS, 2012) secundários autênticos e elevados, as condições subjetivas de superação da auto-alienação e dos estranhamentos: "grande tarefa da cultura socialista, hoje, é a de tornar-se, para os intelectuais, tanto como para as massas, uma pátria espiritual. Nos anos vinte, política e economicamente tão difíceis, isso já fora conseguido em larga medida." Ainda: "Um filme como A balada do soldado de Tchukhrai mostra claramente que o regime stalinista pôde não só limitar mas até extinguir energias criadoras, as quais, contudo, logo ressurgem quando se eliminam as condições desfavoráveis ao seu desenvolvimento". O autor húngaro, não obstante o ar esperançoso, reverbera as consequências, os ecos culturais do dogmatismo-burocratista stalinista: "Com esta afirmação, não quero subestimar as dificuldades do período de transição. Os aparelhos culturais dos países socialistas ainda se acham, em ampla medida, nas mãos de discípulos dogmáticos de Stálin.” (LUKÁCS, 1977, p. 10). E de forma ainda mais radical arremata:

Boa parte dos novos quadros ainda é educada e formada no espírito stalinista. O sistema staliniano é um paraíso para todos os destituídos de talento, que não abrem mão dele com facilidade. Muitos dos elementos mais bem dotados não conseguiram resistir às pressões durante tanto tempo e ressentiram-se gravemente quanto à capacidade e ao caráter. Por tudo isso, penso que a passagem para uma situação cultural que promova realmente a ciência e a arte será, provavelmente, contraditória, difícil, e cheia de recaídas. (LUKÁCS, 1977, p. 10).

Lukács enfatizará a problemática a partir de uma ótica já endossada por ele mesmo em textos anteriores: o processo de democratização do socialismo como injunção fundamental para as relações internas e externas da União Soviética. Libertar-se da "cadeia dos métodos stalinianos" - stalinismo que aparece mais como método operativo do que outra coisa - seria se libertar da insuficiência dogmatista no campo da cultura, e dos limites burocráticos e taticistas no campo da resolução dos problemas mais práticos, sem fazer esquecer a plataforma dessas mudanças, o campo das possibilidades materiais do territorio e do contexto russo. Lukács, sobretudo, enfatiza a necessidade da crítica à luz do dia, revigoramento teórico como persistência do projeto humanista granjeado pelo marxismo autêntico.

A resistência a uma crítica radical e de princípio do período stalinista ainda é muito forte. Nela são invocados os motivos mais disparatados. Há, por exemplo, os ingênuos e bem intencionados que temem que a denúncia desapiedada dos erros do 
sistema stalinista resulte numa perda de prestígio para o comunismo. Estes esquecem que é exatamente nisso que se afirma a força irresistível do comunismo; os movimentos históricos que chegam a amadurecer não podem ser indefinidamente retardados por medidas desfavoráveis, sejam elas quais forem. A expansão e o raio de ação de tais movimentos poderiam ser momentaneamente atingidos, mas não o seu avanço geral. Quando Stálin pertencer integralmente à História e ao passado e não for, como ainda é hoje, o principal obstáculo para uma evolução futura, então será possível, sem maior dificuldade, formular sobre ele um julgamento justo. Pessoalmente, tenho procurado contribuir para esta avaliação histórica equânime. Porém a exigência dela não deve estorvar o trabalho de reforma, que é tão importante. [...] Renunciar a esta "definitividade" burocraticamente decretada, discutir aberta e publicamente as divergências efetivas na ciência e na arte seria imprimir internamente ao marxismo um avanço superior a qualquer previsão e (ao contrário do que pensa a burocracia cultural stalinista) seria aumentar externamente a autoridade dos estudiosos e dos artistas marxistas verdadeiramente capazes. (LUKÁCS, 1977, p. 10).

O "acerto de contas com o presente e com o futuro" é necessário uma vez que se a teoria marxista sofreu "estancamento, o mundo não parou". A crítica lukacsiana não se põe como intelectualismo despropositado. O senso crítico teórico e da práxis são exemplares na biografia do próprio autor (1977, p. 11), que realça: "Faz parte da essência da indagação científica - como da criação artística - que não se possa alcançar um máximo de aproximação da realidade senão através de erros e peripécias múltiplas", ademais "um trabalho sincero de reforma pode produzir resultados novos na ciência e na arte já no curso da luta pela elaboração dos fundamentos da nova fase, embora se trate de um processo longo, complicado e contraditório".

\section{REFERÊNCIAS}

ALBINATI, Ana Selva. Lukács: pensar a ética a partir de Marx. Sapere Aude, Belo Horizonte, v. 6, n. 11, p. 17-30, 2015.

ALVES, Antônio. A crítica marxiana da questão do método. Sapere Aude, Belo Horizonte, v. 6, n. 11, p. 31-68, 2015.

ALVES, Antônio. A questão do Satandpunkt na cientificidade marxiana: a querela do trabalho produtivo na economia política. Revista Verinotio, n.12, p. 86-93, 2010.

ALVES, Antônio. J. Chasin e a descoberta do estatuto ontológico da obra de Marx. Revista Verinotio, n. 9, p. 63-72, 2008.

CHASIN, José. Rota e prospectiva de um projeto marxista. Tomo III: Política. São Paulo: Ad Hominem, 2001.

CHASIN, José. Superação do liberalismo. Maceió, 1988. (mimeo).

KONDER, Leandro. O que é dialética. São Paulo: Brasiliense, 1998. 
LUKÁCS, Georg. Der Spiegel entrevista o filósofo Lukács. Revista Verinotio. n. 9, p. 333 $350,2008$.

LUKÁCS, Georg. Cartas sobre o stalinismo. São Paulo: Temas 1, 1977.

LUKÁCS, Georg. Meu caminho para Marx. Revista Verinotio, n. 12, p. 13-20, 2010.

LUKÁCS, Georg. Para uma ontologia do ser social I. São Paulo: Boitempo, 2012.

LUKÁCS, Georg. Para uma ontologia do ser social II. São Paulo: Boitempo, 2013.

MARX, Karl. A sagrada família. São Paulo: Boitempo, 2003.

MARX, Karl. Crítica da Filosofia do direito de Hegel. São Paulo: Boitempo, 2010.

MARX, Karl. Crítica da Filosofia do direito de Hegel. Introdução. São Paulo: Boitempo, 2010.

MARX, Karl. Manuscritos econômico-filosóficos. São Paulo: Boitempo, 2004.

MESZÁROS, István. Filosofia, ideologia e ciência social. São Paulo: Boitempo, 2008.

NETTO, José Paulo. Lukács e a crítica da filosofia burguesa. Lisboa: Seara Nova, 1978.

SARTORI, Vitor. Marx diante da revolução social na Rússia do século XIX. Revista Verinotio. n. 23 v. 1, p. 126-153, 2017.

TERTULIAN, Nicolas. A destruição da razão: 30 anos depois. Revista Verinotio. n. 13, p. 15-25, 2011.

TONET, Ivo. Método científico. São Paulo: Instituto Lukács, 2013. 